\title{
ГЛОБАЛІЗАЦІЯ ВИЩОЇ ОСВІТИ В РЕСПУБЛІЦІ КОРЕЯ: СТРАТЕГІЧНІ НАПРЯМКИ РОЗВИТКУ Джі Йон Бе
}

Університет митної справи та фінансів

вул. Вернадського, 2/4, м. Дніпро, 49000, Україна. E-mail: Jiana381@gmail.com

Вперше описано стратегічні напрямки розвитку вищої освіти в Республіці Корея: структурна реформа університетів, політика академічного і промислового співробітництва, підтримка студентів, які шукають роботу або розпочинають свою трудову діяльність, активізація корейського масового відкритого освітнього онлайн сервісу Massive Open Online Course. Встановлено, що зазначені стратегічні напрямки розвитку вищої освіти корелюють з глобалізацією корейської освітньої системи в цілому та з ії головними завданнями щодо посилення мультикультурної освіти; підтримки студентів, які переїхали з Північної Кореї; розширення офіційної допомоги на розвиток в освітньому секторі, просування програм студентських обмінів та найкращих міжнародних студентів. Встановлено і описано сутність кожного із стратегічних напрямків розвитку вищої освіти в Республіці Корея, а також обгрунтовано глобалізацію вищої освіти як ііі особливість, що допомагає актуалізувати іï сутність та сприяє кращому розумінню її місії та особливостей у глобалізованому світі. Доведено, що динамічна за своєю суттю сама ідея глобалізації вищої освіти передбачає врахування різних сторін суспільноекономічного розвитку у горизонтальній (глобальний (наднаціональний) / регіональний / національний контекст) та/або вертикальній площинах (глобальний $\rightarrow$ регіональний $\rightarrow$ національний контексти). Подальшого розвитку дістали також положення щодо нових форм навчання та співробітництва.

Ключові слова: глобалізація вищої освіти, структурна реформа університетів, політика академічнопромислового співробітництва, корейський масовий відкритий освітній онлайн сервіс Massive Open Online Course.

\section{ГЛОБАЛИЗАЦИЯ ВЫСШЕГО ОБРАЗОВАНИЯ В РЕСПУБЛИКЕ КОРЕЯ: СТРАТЕГИЧЕСКИЕ НАПРАВЛЕНИЯ РАЗВИТИЯ}

\section{Джи Йон Бэ}

Университет таможенного дела и финансов

Ул. Вернадского, 2/4, г. Днепр, 49000, Украина. E-mail: Jiana381@gmail.com

Впервые описаны стратегические направления развития высшего образования в Республике Корея: структурная реформа университетов, политика академического и промышленного сотрудничества, поддержка студентов, которые ищут работу или начинают свою трудовую деятельность, активизация корейского массового открытого образовательного онлайн сервиса Massive Open Online Course. Установлено, что указанные стратегические направления развития высшего образования коррелируют с глобализацией корейской образовательной системы в целом и с ее основными задачами касательно помощи на развитие в образовательном секторе, продвижения программ студенческих обменов и лучших международных студентов. Установлено и обосновано глобализацию высшего образования как его особенность, что помогает актуализировать его сущность и содействует лучшему пониманию его миссии и особенностей в глобальном мире. Доказано, что динамическая по своей сути сама идея глобализации высшего образования предполагает учет различных сторон социальноэкономического развития в горизонтальной (глобальный (наднациональный) / региональный / национальный контекст) и / или вертикальной плоскостях (глобальный $\rightarrow$ региональный $\rightarrow$ национальный контексты). Дальнейшее развитие получили также положения о новых формах обучения и сотрудничества.

Ключевые слова: глобализация высшего образования, структурная реформа университетов, политика академического и промышленного сотрудничества, корейский массовый открытый онлайн сервис Massive Open Online Course.

АКТУАЛЬНІСТЬ РОБОТИ. Ми живемо в новій парадигмі епохи четвертої промислової революції, коли речі, які ми могли бачити виключно у фантастичних фільмах, такі як штучний інтелект й Інтернет речей, стали частиною нашого повсякденного життя. Особливістю нової парадигми та відмінністю від інших слід визнати той факт, що саме через появу штучного інтелекту та роботів під ії ексклюзивним впливом перебуває міжнародний (глобальний) ринок праці.

Четверта промислова революція поставила перед світом питання, як буде виглядати вища освіта в цьому інтелектуальному інформаційному суспільстві $[1 ; 2 ; 3]$ ? Чи зможуть університети відповідати соціальним запитам цієї нової епохи? Фактично, ми вже починаємо спостерігати невідповідність між університетською освітою і соціальними вимогами на тлі швидких змін у вітчизняному й міжнародному середовищах $[4,5]$. Відповідно, університети постійно докладають зусиль до того, щоб випускники були адаптовані до потреб суспільства, а національні уряди застосовують безліч стратегій для підтримки цієї тенденції.

Науковцями визнана провідна роль освіти у трансформації суспільства до сталості [6], а отже університети відіграють і мають надалі відігравати ключову роль у креативній економіці, створюючи таланти, які можуть займатися творчою діяльністю конвергентно.

Теоретичні основи глобалізації вищої освіти досліджували у своїх працях як вітчизняні, так і зарубіжні науковці. Серед українських дослідників значну роль відіграють праці таких вчених як В. М. Боголюбов [7], І.С. Карпань [8], I.М. Коренева 
[6], О.О. Павленко [9], Н.С. Тимченко-Міхайліді [9], Ю.А. Скиба [10] та ін. Численні дослідження присвячені різним аспектам глобалізації вищої освіти, зокрема глобальним освітнім ресурсам, відкритій освіті тощо. Проте сама ідея глобалізації вищої освіти є динамічною за своєю суттю, оскільки передбачає врахування різних сторін суспільноекономічного розвитку - економічної, соціальної, особистісної - у горизонтальній (глобальний (наднаціональний) / регіональний / національний контекст) та/або вертикальній площинах (глобальний $\rightarrow$ регіональний $\rightarrow$ національний контексти). Саме тому для кожної країни $є$ актуальним сьогодні пошук стратегічних напрямків розвитку вищої освіти, що допоможе актуалізувати іiі сутність та сприятиме кращому розумінню іiї місії та особливостей у глобалізованому світі. Крім того, важливим $є$ інтерпретація стратегічних напрямків розвитку вищої освіти в окремих регіонах світу та в окремих країнах, що стрімко розвиваються.

Метою статті є 3'ясування стратегічних напрямків розвитку вищої освіти в Республіці Корея, встановлення і розкриття їх сутності, а також обгрунтування глобалізації вищої освіти як ії особливості.

МАТЕРІАЛ І РЕЗУЛЬТАТИ ДОСЛІДЖЕНЬ. У дослідженні використано низку теоретичних методів - аналіз, порівняння та систематизація змісту психолого-педагогічної, методичної, навчальної літератури, нормативних документів, структурносистемний аналіз, за допомогою яких було визначено стан розробленості проблеми глобалізації вищої освіти, встановлено сутність та схарактеризовано стратегічні напрямки розвитку вищої освіти в Республіці Корея; узагальнення теоретичних положень, інтерпретація - для обгрунтування глобалізації вищої освіти як ії особливості.

На сьогодні вже загальновизнано, що одним із життєво важливих чинників, що визначають національну конкурентоспроможність, є здатність університетів випускати найкращих випускників, які відповідають вимогам суспільства. Ось чому уряди підтримують безперервні й випереджувальні структурні реформи, щоб університети були конкурентоспроможними та готовими до майбутнього суспільства.

Досліджуючи реформу освіти в Республіці Корея, з'ясовано, що уряд країни також наполягає на тому, щоб проект реформи освіти був спрямований на задоволення потреб суспільства. Представлений нижче невеликий перелік проектів реформи освіти вже дає уявлення про їх широкий структурний спектр та спрямованість. Ось деякі 3 них: проект «Поліпшення освіти в коледжі»/ «Advancement of College Education» (ACE +$)$, проект «Університет для творчої Кореї» (CK) / «University for Creative Korea», проект «Програма навчання відповідно до потреб промисловості» / «PRogram for Industrial needs-Mached Education» (PRIME); ініціатива для проекту «Коледж гуманітарних досліджень та освіти» / «College of humanities' Research and Education» (CORE) та ініціатива «Лідери у проекті співробітництва «Промисловість - університет (коледж)» / «Leaders in Industry-university (college) Cooperation» $(\mathrm{LINC}+)$ [4].
У ході дослідження публічних матеріалів Міністерства освіти Республіки Корея (www.moe.go.kr; http://english.moe.go.kr/) було з'ясовано, що Міністерство освіти визнає глобалізацію корейської освітньої системи в цілому, а тому визначає іiі головні завдання таким чином:

- посилення мультикультурної освіти;

- підтримка студентів, хто переїхали з Північної Кореї;

- розширення офіційної допомоги на розвиток в освітньому секторі;

- просування програм студентських обмінів та найкращих міжнародних студентів [4].

Що ж стосується глобалізації саме вищої освіти в Республіці Корея, то урядом визначено стратегічні напрямки розвитку, пов'язані, передусім, із розвитком інфраструктури університетів та електронним навчанням, посиленням зв'язків із ринком праці. Йдеться про:

- $\quad$ структурну реформу університетів;

- $\quad$ політику академічного і промислового співробітництва та підтримку студентів, які шукають роботу або розпочинають свою трудову діяльність;

- $\quad$ активізацію корейського масового відкритого освітнього онлайн сервісу Massive Open Online Course (K-MOOC).

Розглянемо кожен із стратегічних напрямків розвитку вищої освіти Республіки Корея.

У рамках структурної реформи університетів передбачається, зокрема: 1) впровадження більш релевантної політики у галузі вищої освіти та активізація другого туру університетських структурних реформ; 2) реформування програм фінансової підтримки університетів; 3) заохочення об'єднання університетів та їх закриття; 4) покрокове оцінювання для забезпечення об'єктивної діагностики; 4) індивідуальне оцінювання на основі характеристик університету; 5) використання результатів оцінювання; 6) сприяння розвитку місцевих університетів шляхом розробки спеціалізованих для регіональних галузей навчальних планів [4].

Концептуальні ідеї базуються на тому, що буде надаватися підтримка не тільки окремим університетам, а й заохочуватимуться спільні зусилля університетів, а також злиття і закриття університетів. Шляхом злиття і закриття університетів їх розмір можна стабільно підтримувати в оптимальному діапазоні. Також будуть пропонуватися різні стимули.

Оцінювання на другому турі впровадження структурних реформ передбачається проводити в два етапи, кожен з яких служить різним цілям. На першому етапі діагностується «здатність до самостійного нарощування потенціалу» кожного університету на основі їх власного аналізу стратегії свого розвитку, а також наявність базових елементів для роботи в якості саме інституту вищої освіти.

Якщо університет буде обраний в якості «автономного реформованого університету», він зможе продовжувати працювати на основі власного плану активного розвитку. Міністерство освіти Республіки Корея планує надавати повну адміністративну та фінансову підтримку таким «автономно компетент- 
ним» університетам для поетапного оцінювання 3 метою забезпечення об'єктивної діагностики.

Щодо впровадження політики академічного і промислового співробітництва та підтримки студентів, які шукають роботу або розпочинають свою трудову діяльність, то визначено такі завдання: 1) просування «університетів, пов'язаних з бізнесом» та «підприємств, пов'язаних з університетами»; 2) реалізація програми «Лідери у співробітництві «промисловість - університет» (LINC+); 3) сприяння департаментам, які керуються соціальним замовленням, шляхом гарантування працевлаштування вступникам до університетів; 4) реалізація «Програми навчання відповідно до потреб промисловості» (PRIME); 5) активізація університетських стартапів; 6) розвиток кар'єри та вдосконалення професійної компетентності шляхом систематичної неперервної освіти впродовж кар'єри [4].

Стратегічний напрямок розвитку вищої освіти «активізація корейського масового відкритого освітнього онлайн сервісу Massive Open Online Course» (K-MOOC) передбачає, що буде здійснено: 1) надання якісних університетських лекцій для всіх безкоштовно; 2) розробку лекцій 3 підготовки до четвертої промислової революції; 3) оффлайн зустрічі з видатними вченими; 4) впровадження й розповсюдження як освітньої платформи для майбутнього мобільного додатку К-MOOC; 5) співробітництво між корейськими університетами у ланцюжку «знання - освіта» шляхом розробки й запровадження лекцій для сервісу К-МООС; 6) глобальне поширення корейського масового відкритого освітнього онлайн сервісу Massive Open Online Course (K-MOOC).

Слід визнати стратегічно і тактично правильним напрямок на активізацію роботи корейського масового відкритого освітнього онлайн сервісу КMOОС, який у період стартапів і нарощування у відкритому доступі безкоштовних тематичних освітніх ресурсів пропонує: необмежений доступ до освіти (Massive), відкритий для всіх (Open), через Інтернет (онлайн), і це лекції із заздалегідь визначеною метою навчання (навчальний курс). K-МООС уможливлює інтерактивне навчання, а отже дозволяє проводити такі сесії, як «питання $\rightarrow$ відповіді», дискусії та виконувати різноманітні завдання тощо. 3 моменту своєї появи в Сполучених Штатах у 2012 році, МООС активно запроваджується в Європі й Азії, і знаходиться на шляху просування по всьому світові.

Завдяки розвиненій інфраструктурі ІКТ та електронного навчання, рівню інформатизації вищої освіти в Кореї, Корейський масовий відкритий освітній онлайн сервіс Massive Open Online Course розпочав свою роботу 14 жовтня 2015 року з 27 лекцій від 10 провідних університетів Кореї. Станом на 2017 рік K-МООС налічує близько 300 лекцій від 70 університетів. Своїми високоякісними лекціями К-МООС впроваджує інновації у сфері вищої освіти та сприяє розвитку безперервної освіти в Кореї.

Підтвердженням вищенаведеної думки $\epsilon$ той факт, що платформа зареєструвала 32 мільйони відвідувань і 280000 підписок на лекції (станом на червень 2017 року), відображаючи зростання інтересу з боку тих, хто навчається.

Вивчення віку зареєстрованих користувачів свідчить, що користувачі К-МООС рівномірно розподілені за всіма віковими групами: група до 20 років становила $15 \%$ респондентів, група респондентів віком у 20 років склала $36,9 \%$, група респондентів віком у 30 років - 16,3\%, група респондентів віком у 40 років - 16, 8\%, а група респондентів віком у 50 років і старше становила $14,9 \%$.

У ході дослідження з'ясовано, що на додаток до вже існуючих у сервісі К - МООС 143 лекцій у 2017 році у рамках підготовки до четвертої промислової революції Міністерство освіти Республіки Корея планувало розробити як мінімум ще 160 нових лекцій, щоб довести загальну їх кількість до 300 або й більше лекцій [4].

Нові лекції, додані до сервісу К - МООС у 2017 році, включають лекції, пов'язані з четвертою промисловою революцією, зокрема щодо масивів даних, а також лекції з різних предметів, таких як: гуманітарні науки, кореєзнавство, навчальні дисципліни, які важливі для ринку праці регіонально, тощо. Міністерство освіти Республіки Корея очікує, що розширення сервісу К - МООС дасть змогу обслуговувати різні в епоху четвертої промислової революції i, таким чином, сприятиме навчанню людей у підготовці до майбутнього.

На основі вивчення публічної інформації та документальних джерел можна дійти висновку, що саме тому Міністерство постійно зацікавлене в широкій підтримці високої якості лекцій.

Також з метою залучення до послуговування КМООС постійно університетами, що співпрацюють з сервісом, проводяться різноманітні заходи, на яких передплатники K-MOОС, зокрема в Університеті Ханянг (Hanyang University), проводять зустрічі 3 метою підвищити інтерес до оффлайн зустрічей 3 професорами, які відзначилися, читаючи лекції шляхом використання К-МООС особисто.

Отже, слід констатувати, що поширення корейського масового відкритого освітнього онлайн сервісу Massive Open Online Course уможливлює подальший розвиток наукових положення щодо нових форм навчання та співробітництва як між університетами, там і академічними колами та бізнесспільнотою.

ВИСНОВКИ. Отже, по-перше, сучасний світ живе в новій парадигмі епохи четвертої промислової революції, особливістю якої та ії відмінністю від інших $\epsilon$ той факт, що саме через появу штучного інтелекту та роботів під іiі ексклюзивним впливом перебуває глобальний ринок праці. По-друге, динамічна за своєю суттю ідея глобалізації вищої освіти передбачає врахування різних сторін суспільноекономічного розвитку - економічної, соціальної, особистісної - у горизонтальній (глобальний (наднаціональний) / регіональний / національний контекст) та/або вертикальній площинах (глобальний $\rightarrow$ регіональний $\rightarrow$ національний контексти). По-третє, особливістю вищої освіти в епоху четвертої промислової революції є її глобалізація. 
Саме наукова обгрунтованість головних положень нової парадигми епохи четвертої промислової революції, зокрема й глобалізації вищої освіти, робить для кожної країни сьогодні актуальним пошук стратегічних напрямків розвитку вищої освіти, що допомагає актуалізувати iї сутність та сприяє кращому розумінню іiі місії та особливостей у глобалізованому світі.

Враховуючи важливість інтерпретації стратегічних напрямків розвитку вищої освіти в окремих регіонах світу та в окремих країнах, що стрімко розвиваються, було розкрито стратегічні напрямки розвитку вищої освіти в Республіці Корея, а саме: структурна реформа університетів, політика академічного і промислового співробітництва, підтримка студентів, які шукають роботу або розпочинають свою трудову діяльність, активізація корейського масового відкритого освітнього онлайн сервісу Massive Open Online Course. Ці стратегічні напрямки розвитку вищої освіти корелюють з глобалізацією корейської освітньої системи в цілому та з їі головними завданнями щодо посилення мультикультурної освіти; підтримки студентів, які переїхали з Північної Кореї; розширення офіційної допомоги на розвиток в освітньому секторі; просування програм студентських обмінів та найкращих міжнародних студентів.

Не слід вважати, що глобалізація національних освітніх систем буде безконфліктною і не буде супроводжуватися, навіть за державної фінансової підтримки, боротьбою за ресурси. Протистояти такій ситуації може стратегічне бачення тих, хто розуміє глобальні тенденції розвитку та визначає його національні стратегії, зокрема й стосовно вищої освіти.

\section{ЛІТЕРАТУРА}

1. Поясок Т. Б., Беспарточна О. І. Організація педагогічної взаємодії учасників освітнього процесу в комп'ютерно орієнтованому навчальному середовищі закладу вищої освіти // Інформаційні технології і засоби навчання, Том 67, № 5. 2018, С. 199-212.

2. Павленко О. О. Глобальна освіта: інструментарій Інтернет-технологій // Інформаційні технології і засоби навчання. 2012. № 1 (27). Режим доступу : http://www.journal.iitta.gov.ua
3. Triakina O. O., Pavlenko O. O., Volkova N. P. \& Kassim D. A. (2018). Usage of E-learning Tools in Self-education of Government Officers Involved in Global Trade Activities. // CEUR Workshop Proceedings. ICT in Education, Research and Industrial Applications. Integration, Harmonization and Knowledge Transfer, available at: CEUR-WS.org / Vol. 2257. paper16.pdf

4. Globalization of Korean Education. EDUCATION IN KOREA. Ministry of Education, 2017. 101 p.

5. Колот А. Глобалізація економіки та ії вплив на соціально-трудову сферу. Україна: аспекти праці. 2001. № 3. С. 23-29. Режим доступу: http://ir.kneu.edu.ua/handle/2010/11666

6. Коренева I. М. Орієнтири впровадження освіти для сталого розвитку у вищу педагогічну освіту: сутність та принципи сталого розвитку. Bicник Кременчуцького національного університету імені Михайла Остроградського. Серія «Педагогічні науки». Випуск 2(109). Частина 2. 2018. С. 65-70.

7. Боголюбов В. М. Сталий розвиток суспільства: соціально-екологічні аспекти формування професійної компетентності магістрів-екологів: Монографія. Херсон, 2013. 324 с.

8. Карпань I. С. Освіта для сталого розвитку: кон-цептуальні засади та досвід упровадження : дис. ... канд.філос.наук : 09.00.10. М-во освіти і науки, молоді та спорту України ; Дніпропетровський обласний інститут післядипломної педагогічної освіти. Дніпропетровськ, 2012. 183 с.

9. Павленко О. О., Пугач В. Б., ТимченкоМіхайліді Н. С. Професійна підготовка фахівців у галузі митної справи та зовнішньоекономічної діяльності у контексті глобалізації і стандартизації. Науковий вісник Національного університету біоресурсів і природокористування Украӥни. Серія «Педагогіка. Психологія. Філософія». Редкол.: Д. О. Мельничук (відп. ред.) та ін. К., 2014. Вип. 199. Ч. 1. $437 \mathrm{c}$.

10. Скиба Ю. А. Формування управлінських компетенцій майбутніх екологів на засадах збалансованого розвитку: теорія та практика: монографія. Київ. 2013. 440 с.

\section{GLOBALIZATION OF HIGHER EDUCATION IN THE REPUBLIC OF KOREA: STRATEGIC DIRECTIONS OF DEVELOPMENT}

\section{Gi Yon Bae}

University of Customs and Finance,

vul. Volodymyra Vernadskogo, 2/4, Dnipro, 49000, Ukraine. E-mail: Jiana381@gmail.com

Purpose. The purpose of the article is to figure out the strategic directions of higher education development in the Republic of Korea, identify and reveal its essence as well as provide a basis for the higher education globalization as its peculiarity. Methodology. A number of theoretical methods is used in the research, such as analysis, comparison and systematization of the content of psychological and pedagogical, methodological and educational literature, normative documents, structural and system analysis, through which the state of development of the problem of globalization of higher education was determined, the essence and characterization of the strategic directions of higher education development in the Republic of Korea were given; generalization of theoretical regulations and their interpretation were conducted to substantiate the globalization of higher education as its peculiarity. Results. Considering the importance of interpretation of strategic directions of higher education development in certain regions of the world and in certain rapidly developing countries, the author discovered the strategic directions of higher education development in the Republic of Korea, which are the Structural Reform of Universities and Promotion of Local Universities; Academic-Industrial Cooperation Policies and Support for Students Searching for Jobs or Starting Businesses; Invigoration of Korean Mas- 
sive Open Online Course Service (K-MOOC). In addition, the author identified and described in the article the essence of each of the strategic directions of higher education development in the Republic of Korea. These strategic directions of higher education development correlate with the globalization of the Korean educational system in general and with its' tasks related to Reinforcement of Multicultural Education; Support for Students Defected from North Korea; Expansion of Official Development Assistance in the Education Sector; Promotion of Student Exchange Programs and Outstanding International Students. The peculiarity of higher education in the era of the fourth industrial revolution is its globalization. Originality. The scientific novelty of the research results presented in the article lies in the fact that for the first time the strategic directions of higher education development in the Republic of Korea in the context of the higher education globalization were developed. The new forms of teaching and cooperation are further developed. Practical value. Ascertainment of the strategic directions of higher education development in the Republic of Korea, revelation of its' essence will help promote better understanding of globalization processes occurring in the field of higher education and the labor market. Interpretation of the strategic directions of higher education in accordance with the educational process of universities will facilitate the introduction of relevant education into the practice of training competitive future professionals. Conclusion. Nowadays higher education is developing in a new paradigm of the age of the Fourth Industrial Revolution, which peculiarity and distinction from others lies in the fact that due to the emergence of artificial intelligence and robots the global labor market is under its exclusive influence. Scientific validation of the main provisions of a new paradigm of the age of the Fourth Industrial Revolution, in particular the globalization of higher education, makes a search for the strategic directions of higher education development actual for each country today, that helps actualize its essence and contribute to a better understanding of its mission and features in a globalized world. Therefore, the dynamic idea of the globalization of higher education itself implies taking into account the various aspects of socioeconomic development - economic, social, personal - in the horizontal (global (supranational) / regional / national context) and / or vertical planes (global $\rightarrow$ regional $\rightarrow$ national contexts).

Key words: globalization of higher education, Structural Reform of Universities, Academic-Industrial Cooperation Policies, the Korean Massive Open Online Course Service.

\section{REFERENCES}

1. Poyasok, T. B., Bespartochna, O. I. (2018), "Arrangement of pedagogical interaction among the education process participants in computer-oriented educational environment of higher education institution", Information Technologies and Learning Tools, Vol. 67, no. 5, pp.199-212.

2. Pavlenko, O. (2012), "Global Education: Internet-Technology Instruments", Information Technologies and Learning Tools, no. 1 (27), available at: http://www.journal.iitta.gov.ua

3. Triakina, O. O., Pavlenko, O. O., Volkova, N. P., Kassim, D. A. (2018). "Usage of E-learning Tools in Self-education of Government Officers Involved in Global Trade Activities", CEUR Workshop Proceedings. ICT in Education, Research and Industrial Applications. Integration, Harmonization and Knowledge Transfer, available at: CEUR-WS.org/Vol2257/paper16.pdf

4. Globalization of Korean Education. Education in Korea. (2017). Ministry of Education, Korea, 101 p.

5. Kolot, A. (2001), "Globalization of the economy and its impact on the social and labor sphere", Ukraina: aspekty pratsi, no. 3, pp. 23-29, available at: http://ir.kneu.edu.ua/handle/2010/11666

6. Koreneva, I. M. (2018), "Guidelines of the implementation of education for sustainable development in higher pedagogical education: the core and principles of sustainable development", Transactions of Kremenchuk Mykhailo Ostrohradskyi National University, Seriia «Pedahohichni nauky», iss. 2(109), part 2, pp. 65-70.
7. Boholiubov, V. M. (2013), Stalyi rozvytok suspilstva: sotsialno-ekolohichni aspekty formuvannia profesiinoi kompetentnosti mahistriv-ekolohiv: Monohrafiia [Sustainable development of society: socio-environmental aspects of the formation of professional competence of masters of ecology: Monograph], Hrin D.S., Kherson, Ukraine.

8. Karpan, I. S. (2012), Osvita dlia staloho rozvytku: kontseptualni zasady ta dosvid uprovadzhennia : dis. ... kand.filos.nauk [Education for Sustainable Development: Conceptual Foundations and Implementation Experience]. Ph.D. thesis. Dnipropetrovsk Regional Institute of Postgraduate Pedagogical Education, Dnipropetrovsk, Ukraine, $183 \mathrm{p}$.

9. Pavlenko, O. O., Pugach, V. B., TymchenkoMikhailidi, N. S. (2014), "Professional training of specialists in the customs domain and foreign economic activity in the context of globalization and standardization", Naukovyi visnyk Natsionalnoho universytetu bioresursiv $i$ pryrodokorystuvannia Ukrainy, Seriia «Pedahohika. Psykholohiia. Filosofiia», iss.199, part 1, 437 p., available at: http://nbuv.gov.ua/UJRN/nvnau_ped_2014_199(1)_43.

10. Skyba, Y. A. (2013), Formuvannia upravlinskykh kompetentsii maibutnikh ekolohiv na zasadakh zbalansovanoho rozvytku: teoriia ta praktyka: monohrafiia. [Formation of managerial competences of future ecologists on the principles of balanced development: theory and practice: monograph], Kiev, Ukraine. 